\title{
Microbial $\beta$-glucan Incorporated into Muffins: Impact on Quality of the Batter and Baked Products
}

\author{
Anna Żbikowska ${ }^{1}$, Milena Kupiec ${ }^{1}{ }^{\circledR}$, Iwona Szymanska ${ }^{1} \mathbb{C}$, Klaudia Osytek $^{1}$, \\ Małgorzata Kowalska ${ }^{2}$ D, Katarzyna Marciniak-Lukasiak ${ }^{1, * \mathbb{D}}$ and Jaroslawa Rutkowska ${ }^{3}$ (D) \\ 1 Institute of Food Sciences, Faculty of Food Assessment and Technology, Warsaw University of Life \\ Sciences (WULS-SGGW), Nowoursynowska st.159c, 02-776 Warsaw, Poland; \\ anna_zbikowska@sggw.pl (A.Ż.); milena_kupiec@sggw.pl (M.K.); iwona_szymanska@sggw.pl (I.S.); \\ klaudia_osytek@sggw.pl (K.O.) \\ 2 Faculty of Chemical Engineering and Commodity Science, Kazimierz Pulaski University of Technology and \\ Humanities, Chrobrego st, 27, 26-600 Radom, Poland; mkowalska7@vp.pl \\ 3 Institute of Human Nutrition Sciences, Faculty of Human Nutrition, Warsaw University of Life \\ Sciences (WULS-SGGW), Nowoursynowska st.159c, 02-776 Warsaw, Poland; jaroslawa_rutkowska@sggw.pl \\ * Correspondence: katarzyna_marciniak_lukasiak@sggw.pl; Tel.: +48-22-593-7548
}

Received: 2 March 2020; Accepted: 10 April 2020; Published: 14 April 2020

\begin{abstract}
Microorganisms can be a promising source of bioactive food ingredients derived from unconventional agricultural farms. The quality of batter and final products in which $20 \%-80 \%$ of the fat has been replaced by $\beta$-glucan, obtained from microorganisms, was analyzed. The instrumental texture measurements showed that $\beta$-glucan batter and muffins were harder than the control sample. Fat substitution over $40 \%$, while enriching muffins with yeast $\beta$-glucan (over $2 \%$ ), led to a decrease in the quality of products after baking and during 14-day storage. The incorporation of $3 \%$ or more $\beta$-glucan into the composition increased the hardness of the batter and deteriorated the quality of the muffin crumb, after baking and during storage. The sensory study revealed that fat replacement up to $40 \%$ with $\beta$-glucan provided acceptable biscuits, but higher replacement decreased the overall acceptability.
\end{abstract}

Keywords: yeast $\beta$-glucan; bakery products; fat replacer; sensory analysis; texture; functional food

\section{Introduction}

The world's population is still growing, which requires an increase in food supply. According to Food and Agriculture Organization (FAO), food production should double by 2050 to meet the nutritional needs of the entire population. However, the resources used so far are limited as the arable land area is decreasing and global water resources are running out [1]. That is why more and more attention is paid to new food sources and modern technologies of agricultural production, for example microbial biomass. The production of such organisms is supported by, among others, high production efficiency resulting from their rapid growth and independence from seasonal factors [2]. Microorganisms can also provide nutritious nutrients-bioactive substances such as $\beta$-glucan. This polysaccharide accounts for about $60 \%$ of the dry substance (DS) of the yeast cell wall and $12-14 \%$ DS on a whole cell basis. Yeast yields both water-soluble and water-insoluble $\beta$-glucan [3].

$\beta$-glucan is one of the components of valuable dietary fiber, which has huge health-promoting applications. It was found that $\beta$-glucan as an active ingredient has a promising effect in wound healing [4]. Its immunotherapeutic properties have been described, including the reinforcement of the anti-tumor immunity response. These properties are mainly associated with the stimulation of innate immune cells [5]. The effect of $\beta$-glucan on blood cholesterol is widely described in the literature. 
Because of the relatively high consumption of oats, the most attention was paid to the relationship of oat glucan with cholesterol. These glucans have been found to lower serum cholesterol in both animals and humans. In addition, glucans, especially those in human food, play a positive role in metabolic control of diabetes [6].

Bakery products are a popular snacks product with high consumer acceptance [7]. They contain large amounts of fat, which performs multiple important functions in such products. Fat is the ingredient responsible for keeping high sensory quality of products (characteristic color, flavor, tenderness of texture, mouthfeel, general product appearance) and shelf life tenderness [8-10]. Fats has a high energy value, and shortening usually has a high content of saturated fatty acids (SFA) and sometimes trans isomers [11] which can lead to civilization diseases [12]. According to WHO recommendations, the level of fat in the diet should be reduced, and the daily intake of SFA should not exceed $10 \%$. A large majority of European population exceeds this recommended limit [13]. Cake products are a significant source of SFA and fat in the diet $[14,15]$. Scientists are still trying to reduce the fat content and SFA of food and introduce bioactive ingredients that increase its health value. Therefore, the aim of this study is to assess the effects of the content of $\beta$-glucan (microbiological origin) used as a fat replacer on the properties of the batter and on the physical and sensory properties of the muffins. Results of analyzes obtained for new products were compared to full-fat bakery goods.

\section{Materials and Methods}

\subsection{Materials}

Properties of batter and baked products (muffins) were studied. Control batter ingredients: wheat flour type 480 (Polskie Młyny SA, Poland), rapeseed oil (ZT Kruszwica SA, Poland), 3.2\% fat milk (Mlekpol, Poland), sugar (Diamant, Środa Wielkopolska, Poland), fresh eggs (Farmio SA Warsaw, Poland), sodium bicarbonate, and ammonium hydrogen carbonate (Zakłady Azotowe Chorzów SA, Chorzów, Poland) were purchased locally.

Yeast $\beta$-glucan preparation (Biothera, USA) containing $91.31 \%$ of polysaccharide in dry mass (soluble fiber) was added in the quantity of $1.0 \%, 2.0 \%, 3.0 \%$, and $4.0 \%$ of the all mass of batter (samples: MBG1, MBG2, MBG3, MBG4, respectively). $\beta$-glucan was used as a fat replacer in a 1:4 ratio. The fat content was reduced by $20,40,60$, and $80 \%$ compared to the control sample without the fat replacement. The sample formulas are shown in Table 1.

Table 1. Formulas of analyzed muffins.

\begin{tabular}{cccccc}
\hline \multirow{2}{*}{$\begin{array}{c}\text { Ingredients } \\
\text { (g/100 g batter) }\end{array}$} & MBG0 (control) & MBG1 & MBG2 & MBG3 & MBG4 \\
\hline Flour & 34 & 34 & 34 & 34 & 34 \\
Milk & 17 & 17 & 17 & 17 & 17 \\
Eggs & 12 & 12 & 12 & 12 & 12 \\
Oil & 20 & 16 & 12 & 8 & 4 \\
Sodium bicarbonate & 0.4 & 0.4 & 0.4 & 0.4 & 0.4 \\
Ammonium bicarbonate & 0.4 & 0.4 & 0.4 & 0.4 & 0.4 \\
Sugar & 16.2 & 16.2 & 16.2 & 16.2 & 16.2 \\
$\beta$-glucan & 0 & 1 & 2 & 3 & 4 \\
\hline
\end{tabular}

1 -MBG0 — control sample ( $0 \%$ of yeast $\beta$-glucan content and $100 \%$ of fat content), MBG1—sample with $1 \%$ of yeast $\beta$-glucan content and $80 \%$ of fat content, MBG2-sample with $2 \%$ of yeast $\beta$-glucan content and $60 \%$ of fat content, MBG3 - sample with $3 \%$ of yeast $\beta$-glucan content and $40 \%$ of fat content, MBG4 -sample with $4 \%$ of yeast $\beta$-glucan content and $20 \%$ of fat content.

The introduction of a health-promoting ingredient into the muffin composition allows them to be classified as functional food. In accordance with the provisions in force, foods enriched with fiber can be labeled nutritious [16]. 


\subsection{Muffins Preparation}

Oil, eggs, and milk (liquid ingredients) were stirred for $120 \mathrm{~s}$ using the Braun Multiquick kitchen processor (type 4644) to obtain a creamy texture. Wheat flour, sugar, sodium bicarbonate, and ammonium hydrogen carbonate, $\beta$-glucan preparation (dry ingredients), were weighed and mixed. This mixture was then added to previously whipped liquid ingredients and mixed for 120 seconds. After filling the batter into baking cups in $64 \pm 0.2 \mathrm{~g}$ aliquots, the batter was baked in the UNOX type XBC convection oven (Vie Dell Ariginato, Padowa, Italy) at $175^{\circ} \mathrm{C}$ for 17 minutes. Muffins were made and analyzed $24 \mathrm{~h}$ after baking. Each baking was repeated three times.

\subsection{Storage Test}

The muffins were stored for 1,7 , and 14 days in polyethylene bags at $21 \pm 2{ }^{\circ} \mathrm{C}$. The products were stored in the dark with $45 \%$ humidity.

\subsection{Methods}

\subsubsection{Batter Texture Analysis}

The texture of the batter was measured using a texture analyzer TA.TX.plus (Stable Micro Systems, London, UK). The penetration test was carried out at room temperature. A tip P/0.5R was used for the measurement, which was immersed in the sample to a depth of $5 \mathrm{~mm}$ with a speed of $1 \mathrm{~mm} / \mathrm{s}$. A $20 \mathrm{~g}$ sample of batter was placed in a $3 \mathrm{~cm}$ diameter cylinder. The highest measured force value was defined as batter hardness expressed in Newtons [17]. Ten batters from each variant were measured.

\subsubsection{Volume of Muffins and Crumb Density}

The volume of the muffins was determined using rapeseed displacement method. The crumb density was calculated by cutting a cube of $2 \times 2 \times 2 \mathrm{~cm}$ from the inside of the baked products and weighing it [18]. This analysis was carried out in nine repetitions.

\subsubsection{Geometry}

Dimensions of baked products were determined: width (diameter $\mathrm{D})$ and height $(\mathrm{H})$ at the maximum point using an electronic caliper (TCM, type: 234990, Tchibo, Germany). Based on the average $\mathrm{D}$ and height $\mathrm{H}$ of muffins, a spreadability index (SI) was calculated from the formula: $\mathrm{SI}=\mathrm{D} / \mathrm{H}$.

\subsubsection{Moisture Content}

The water content of the muffins was determined in triplicate in each variant. The samples were grinded in a mill and transferred $(3 \mathrm{~g})$ to a weighted moisture dishes and were placed in a laboratory dryer at $103 \pm 2{ }^{\circ} \mathrm{C}$ for $3 \mathrm{~h}$. Water content was calculated as the difference in weight before and after drying in percentage.

\subsubsection{Instrumental Analysis of the Crumb Texture}

The texture properties of the products were determined using a TA-XT2i texture analyzer (Stable Micro Systems, London, UK, $5 \mathrm{~kg}$ load cell). Double compression test (TPA) was carried out. Cubes $(20 \times 20 \times 20 \mathrm{~mm})$ were compressed using P/36R tip, until relative compression was $50 \%$. Hardness, cohesiveness, springiness, and chewiness of products were determined. Hardness and chewiness were expressed in Newton's. The assay was undertaken at room temperature $\left(23 \pm 2{ }^{\circ} \mathrm{C}\right)$. The final result was calculated as a mean of 12 measurements. 


\subsubsection{Sensory Analysis}

The quantitative descriptive analysis (QDA) method provides a full sensory description of the product [19]. The sensory evaluation was conducted by a trained 15-person team. The assessors chose the descriptors and discussed their definition. Selected attributes focused on various aspects of the external characteristics (including typical color, evenness of bake, cracking on the surface), crumb appearance (typical color, uniformity of color, porosity), textures (hardness, springiness, gumminess), smell and taste (typical, oil, foreign), and overall quality. The intensity of sensory attributes was evaluated on 10-cm undivided linear scales. Samples were randomly selected from each batch and given in random order, each in a separate plastic box marked with a code. Panelists rinsed their mouths with water between sample assessments.

\subsubsection{Data Analysis}

The effects of the content of $\beta$-glucan replacement on properties of batter and baked products were performed using one-way ANOVA and regression. The assessment of the significance of differences between the means was performed using Duncan's procedure with $p<0.05$. Also the regression method was used for model determination ( $\times$-the quantity of addition of $\beta$-glucan preparation). Changes in the values of texture parameters and water content of baked products are graphically presented in the Figures. Statistical analysis was conducted with Statistica 13.3.0 software package (TIBCO Software Inc., Palo Alto, CA, USA).

\section{Results}

\subsection{Analysis of Measurements of Batter}

Fat significantly improves the properties of the batter. It traps air, giving a creamy and uniform consistency. Reducing its amount in the composition can negatively affect these characteristics. The quality of batter affects the properties of the final product $[20,21]$. The reduction in fat content, and thus, the increase in the addition of $\beta$-glucan preparation caused a significant increase in hardness by up to about $67 \%$ (from $0.12 \mathrm{~N}$-control sample (MBG0) to $0.20 \mathrm{~N}$-sample (MBG4) with $4 \%$ addition). The smallest hardness was found in semi-finished products without the addition of $\beta$-glucan and MBG 1 products (with a reduced fat content by $20 \%$ ) - $0.12 \mathrm{~N}$ (Figure 1 ).

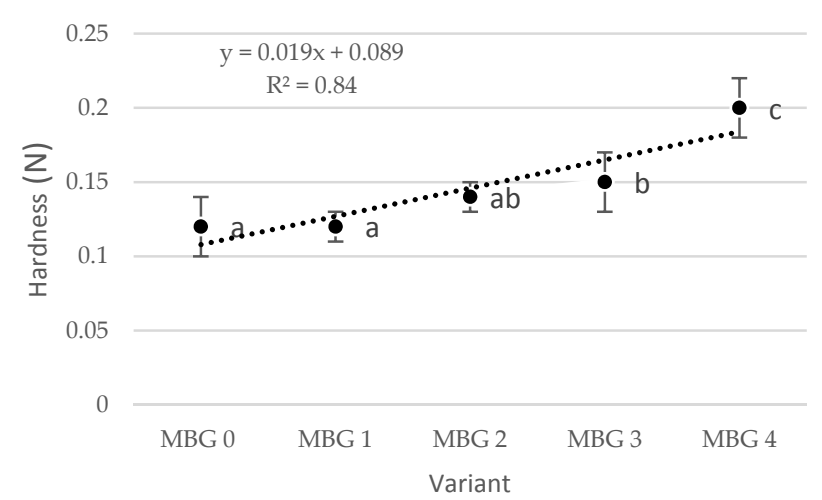

Figure 1. Hardness of batter. MBG0 - control sample ( $0 \%$ of yeast $\beta$-glucan content and $100 \%$ of fat content), MBG1-sample with $1 \%$ of yeast $\beta$-glucan content and $80 \%$ of fat content, MBG2-sample with $2 \%$ of yeast $\beta$-glucan content and $60 \%$ of fat content, MBG3-sample with $3 \%$ of yeast $\beta$-glucan content and $40 \%$ of fat content, MBG4 - sample with $4 \%$ of yeast $\beta$-glucan content and $20 \%$ of fat content; $\mathrm{a}, \mathrm{b}, \mathrm{c}-$ homogenous groups, $p \leq 0.05$.

The parameter values increased significantly $(p<0.05)$ by increasing the amount of fat replacement at various levels of fat reduction. This upward trend, along with the increase in the amount of fat substitute used, can be explained by the high water glucan absorption capacity. Similar observations 
were made by Ghodke [22], Serin and Sayar [23] including chapatti and pogaca dough on the amount of guar gum and carbohydrates. Previous studies have shown that a decrease in gluten binding capacity because of the high water absorption of ingredients used in batter formulations leads to the formation of a sticky structure [22-24].

\subsection{Analysis of Physical Measurements of Muffins}

There were no statistically significant differences $(p<0.05)$ between the weight of muffins (Table 2$)$. However, different volumes (v) of the obtained products were noted. Control muffins (MBG0) had the highest value of this parameter. The addition of $\beta$-glucan caused a decrease in volume without a statistically significant effect on the change in mass during baking. Thus, it caused an increase in crumb density. Muffins with the highest $\beta$-glucan content and the lowest fat content were characterized by the highest crumb density (Table 2). Large amounts of fat in the biscuit recipe ensure a finely porous crumb structure, as well as high lightness and delicacy [25]. Other scientists have also reported a reduction in baking volume when fat has been replaced with substitutes such as e.g., various $\beta$-glucans, maltodextrin, polydextrose $[18,23,26]$. Fat reduction decreases the amount of air bubbles that are introduced into the batter during whipping and expand during baking [27].

The diameter of muffins with a $1-3 \%$ addition of $\beta$-glucan did not differ statistically significantly from the control variant (MBG0). Bakery goods were even less varied in thickness (Table 2). However, it was found that $2-4 \%$ addition of microbial preparation have an impact on the spread ratio of muffins.

The water content in the muffins varied and increased depending on the $\beta$-glucan dose. The lowest water content was observed in the control samples after baking. Products with the largest $\beta$-glucan additives were characterized by the highest humidity. The increased value of the measured parameter in products may reflect the ability of microbial polysaccharide to retain more water. Similar results were observed in other works in which various types of fat substitutes were used (maltodextrin, polydextrose, apple fiber, inulin $[21,23,28])$. This is due to the ability of fat substitutes to bind and retain significant amounts of water [29]. The introduction of larger amounts of $\beta$-glucan into muffins resulted in the binding of a larger amount of water introduced into the dough together with the raw materials, and less moisture loss during baking the batter.

\subsection{Texture Profile Analysis (TPA)}

Fat is an important ingredient of biscuits, which has a big impact on the texture of the products. As we reported in previous works, reducing fat content or replacing fat with various ingredients has a huge impact on the texture parameters of bakery products $[21,30,31]$. The texture parameters tested are shown in Figure 2.

In this study one observed an increase in the hardness of the muffin crumb with an increase in the $\beta$-glucan content and a decrease in the amount of fat in the product (from $3.17 \mathrm{~N}$ - control to $7.03 \mathrm{~N}$ - samples with $4 \%$ addition). However, only the hardness of the MBG4 sample differed statistically significantly $(p<0.05)$ from the others. In opinion of Martinez-Cevera et al. [32], muffin hardness is inversely related to its volume. So, the smaller volume of products, the harder the muffin is. This is confirmed by the results obtained, in which the volume of MBG4 was statistically significantly lowered and hardened in texture compared to the control muffin. Rodríguez-García et al. [33] reported that hardness is related to the all air cell volume and volume of crumb of products. As the size of the gas cell increases, the bakery product has a softer crumb. Well aerated and springiness product crumb, with high values of springiness, is recognized as high quality foods [34]. A similar tendency was observed in the case of chewiness (Figure 1). It is an additional key texture parameter that is primarily associated with the difficulty of chewing before swallowing [35]. The highest fat replacement (MBG4) showed the hardest, the most difficult to chew, and not very springiness texture. After applying the regression analysis, we obtained the strongest $(R 2=0.99)$ model: springiness $=-0.018 x+0.902$ (Figure 2). 
Table 2. Properties of muffins ${ }^{1}$.

\begin{tabular}{|c|c|c|c|c|c|c|c|c|}
\hline Formulation & $\begin{array}{c}\text { Fat reduction } \\
(\%)\end{array}$ & Weight (g) & Volume $\left(\mathrm{cm}^{3}\right)$ & $\begin{array}{l}\text { Crumb Density } \\
\left(\mathrm{g} / \mathrm{cm}^{3}\right)\end{array}$ & $\begin{array}{l}\text { Diameter (mm) } \\
\text { (D) }\end{array}$ & $\begin{array}{l}\text { Thickness } \\
(\mathrm{mm})(\mathrm{T})\end{array}$ & $\begin{array}{c}\text { Spread Ratio } \\
(\mathrm{D} / \mathrm{T})\end{array}$ & $\begin{array}{c}\text { Water Content } \\
\text { (\%) }\end{array}$ \\
\hline MBG0 & 0 & $55.4 \pm 0.4 \mathrm{~b}$ & $113.3 \pm 1.40 \mathrm{c}$ & $0.490 \pm 0.09 a$ & $61.86 \pm 1.13 \mathrm{ab}$ & $56.6 \pm 1.01 \mathrm{~b}$ & 1.09 & $17.97 \pm 3.01 \mathrm{a}$ \\
\hline MBG1 & 20 & $55.2 \pm 0.2 \mathrm{~b}$ & $112.5 \pm 1.63 b c$ & $0.491 \pm 0.09 \mathrm{a}$ & $61.08 \pm 1.27 \mathrm{a}$ & $56.01 \pm 2.71 b$ & 1.09 & $19.26 \pm 1.54 \mathrm{ab}$ \\
\hline MBG2 & 40 & $55.5 \pm 0.2 b$ & $111.2 \pm 1.71 \mathrm{abc}$ & $0.499 \pm 0.07 \mathrm{ab}$ & $62.71 \pm 0.21 \mathrm{ab}$ & $53.73 \pm 2.05 b$ & 1.16 & $20.21 \pm 1.42 b$ \\
\hline MBG3 & 60 & $55.6 \pm 0.1 b$ & $110.0 \pm 2.18 \mathrm{ab}$ & $0.506 \pm 0.10 \mathrm{~b}$ & $66.36 \pm 1.36 b c$ & $51.02 \pm 3.01 \mathrm{ab}$ & 1.18 & $21.20 \pm 1.32 b c$ \\
\hline MBG4 & 80 & $55.1 \pm 0.35 b$ & $108.3 \pm 2.12 \mathrm{a}$ & $0.507 \pm 0.09 b$ & $68.83 \pm 4.12 c$ & $47.46 \pm 3.04 \mathrm{a}$ & 1.45 & $24.04 \pm 1.45 c$ \\
\hline
\end{tabular}
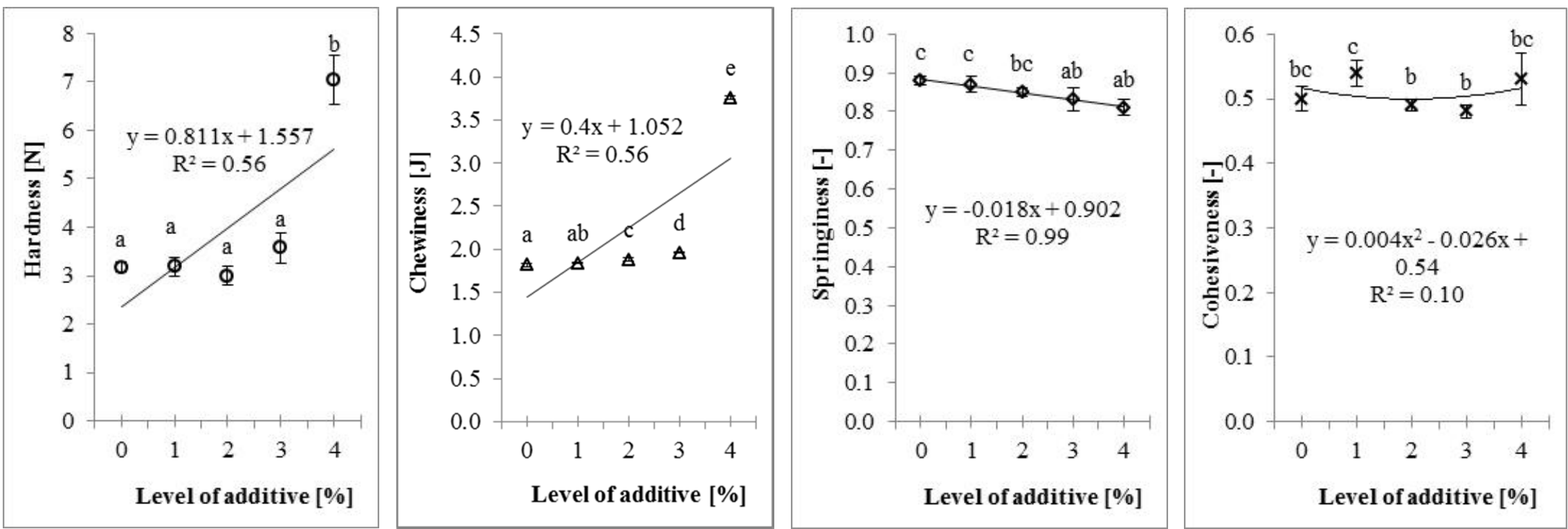

Figure 2. Textural properties of muffins. a, b, c-describes homogenous groups, $p \leq 0.05$. Numbers $0,1,2,3,4$ correspond to the analyzed samples (MBG0, MBG1, MBG2, MBG3, MBG4 respectively). 


\subsection{Sensory Analysis}

Fat plays an important role in sensory evaluation of the products. This ingredient is responsible for mouthfeel, taste, texture delicacy, color, and overall product appearance [8]. The substitution of fat with $\beta$-glucan affected the sensory quality of muffins (appearance, texture, smell, and taste). The results for the evaluated samples are shown in Table 3.

Table 3. Descriptive sensory scores ${ }^{1}$.

\begin{tabular}{|c|c|c|c|c|c|}
\hline $\begin{array}{ll}\text { Sensory Characteristics } & \text { Formulation } \\
\end{array}$ & MBG0 & MBG1 & MBG2 & MBG3 & MBG4 \\
\hline \multicolumn{6}{|c|}{ The external appearance of the muffin } \\
\hline Evenness of bake & $8.27 \mathrm{~b}$ & $8.0 \mathrm{~b}$ & $7.73 \mathrm{~b}$ & $6.41 \mathrm{a}$ & $6.18 \mathrm{a}$ \\
\hline SD & 0.69 & 1.62 & 1.53 & 1.72 & 1.22 \\
\hline Cracking on the surface & $8.20 \mathrm{~b}$ & $7.56 \mathrm{~b}$ & $7.44 \mathrm{~b}$ & $7.06 \mathrm{~b}$ & $4.94 \mathrm{a}$ \\
\hline SD & 01.10 & 1.31 & 1.06 & 1.42 & 1.44 \\
\hline Typical color & $6.39 c$ & $6.12 c$ & $4.01 \mathrm{~b}$ & $2.54 \mathrm{a}$ & $2.37 \mathrm{a}$ \\
\hline SD & 1.63 & 1.79 & 1.34 & 1.65 & 1.07 \\
\hline \multicolumn{6}{|c|}{ The appearance of the crumb } \\
\hline Uniformity of color & $7.60 \mathrm{bc}$ & $8.38 \mathrm{c}$ & $7.74 \mathrm{bc}$ & $6.86 \mathrm{~b}$ & $5.82 \mathrm{a}$ \\
\hline $\mathrm{SD}$ & 1.17 & 1.65 & 0.59 & 0.74 & 1.64 \\
\hline Porosity & $1.14 \mathrm{a}$ & $2.14 \mathrm{~b}$ & $2.23 \mathrm{~b}$ & $3.58 \mathrm{c}$ & $3.16 \mathrm{c}$ \\
\hline $\mathrm{SD}$ & 0.90 & 0.94 & 0.99 & 0.86 & 1.33 \\
\hline Typical color & $1.78 \mathrm{a}$ & $1.85 \mathrm{a}$ & $1.99 \mathrm{a}$ & $3.37 \mathrm{~b}$ & $5.44 \mathrm{c}$ \\
\hline SD & 0.80 & 0.86 & 0.96 & 0.72 & 1.94 \\
\hline \multicolumn{6}{|c|}{ Texture } \\
\hline Hardness & $1.17 \mathrm{a}$ & $1.83 \mathrm{a}$ & $2.98 \mathrm{~b}$ & $3.99 \mathrm{bc}$ & $5.34 \mathrm{c}$ \\
\hline SD & 0.96 & 1.24 & 0.94 & 1.21 & 1.92 \\
\hline Springiness & $6.10 \mathrm{c}$ & $5.54 \mathrm{bc}$ & $4.50 \mathrm{ab}$ & $4.16 \mathrm{a}$ & $3.78 \mathrm{a}$ \\
\hline SD & 1.52 & 0.78 & 1.09 & 1.18 & 1.12 \\
\hline Guminess & $4.61 \mathrm{~b}$ & $4.37 \mathrm{ab}$ & $4.88 \mathrm{~b}$ & $3.94 \mathrm{ab}$ & $3.44 \mathrm{a}$ \\
\hline SD & 0.95 & 1.28 & 1.54 & 0.89 & 0.87 \\
\hline \multicolumn{6}{|c|}{ Odor } \\
\hline Typical & $7.46 \mathrm{~b}$ & $7.47 \mathrm{~b}$ & $6.52 \mathrm{~b}$ & $6.36 \mathrm{~b}$ & $4.07 \mathrm{a}$ \\
\hline SD & 1.07 & 1.50 & 0.91 & 1.08 & 1.31 \\
\hline Oil & $8.68 \mathrm{e}$ & $7.83 \mathrm{~d}$ & $6.79 c$ & $4.35 \mathrm{~b}$ & $2.52 \mathrm{a}$ \\
\hline SD & 0.52 & 0.84 & 0.94 & 1.03 & 1.11 \\
\hline Foreign & $0.80 \mathrm{a}$ & $1.10 \mathrm{ab}$ & $1.28 \mathrm{ab}$ & $1.47 \mathrm{ab}$ & $1.78 \mathrm{~b}$ \\
\hline SD & 0.74 & 0.72 & 0.82 & 0.94 & 0.67 \\
\hline \multicolumn{6}{|c|}{ Flavor } \\
\hline Typical & $9.09 \mathrm{c}$ & $5.76 \mathrm{c}$ & $5.85 c$ & $4.74 \mathrm{~b}$ & $3.56 \mathrm{a}$ \\
\hline SD & 0.92 & 1.11 & 0.76 & 1.72 & 1.92 \\
\hline Oil & $7.03 \mathrm{c}$ & $5.60 \mathrm{bc}$ & $4.85 \mathrm{bc}$ & $3.59 \mathrm{ab}$ & $2.86 \mathrm{a}$ \\
\hline SD & 1.23 & 1.26 & 1.09 & 1.05 & 1.75 \\
\hline Foreign & $0.81 \mathrm{a}$ & $2.47 \mathrm{~b}$ & $3.21 \mathrm{bc}$ & $4.06 \mathrm{~cd}$ & $4.17 \mathrm{~d}$ \\
\hline SD & 0.79 & 0.93 & 1.05 & 1.29 & 2.15 \\
\hline
\end{tabular}

\footnotetext{
${ }^{1} \mathrm{a}, \mathrm{b}, \mathrm{c}$-describes homogenous groups, $p \leq 0.05$, other explanations as described under Figure 1.
}

The elimination of oil from the recipe resulted in a decrease in sensory quality of the tested products (Figure 3). 


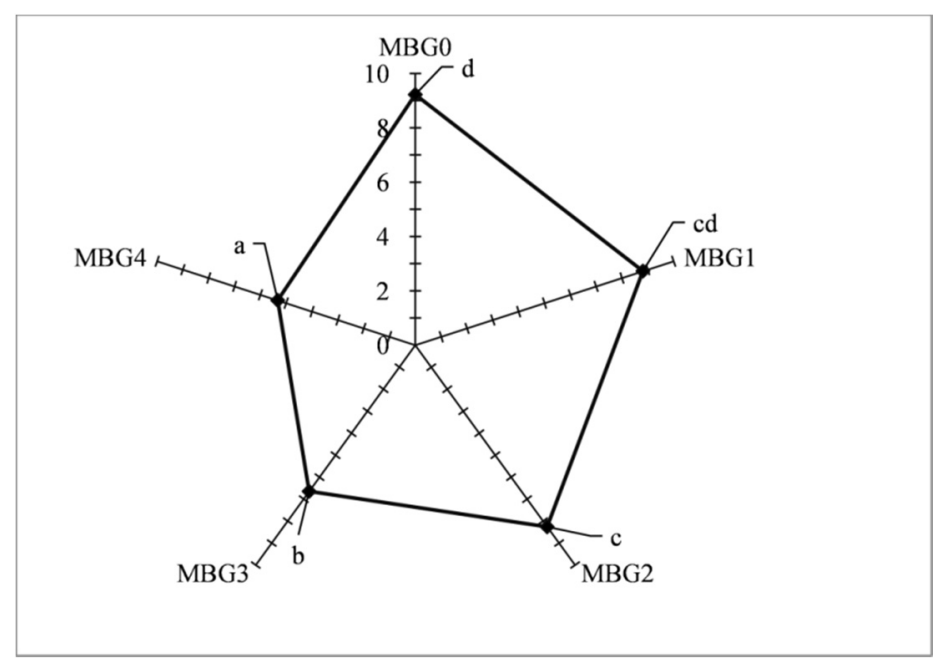

Figure 3. Mean overall quality of control and reformulated muffins. a,b,c-describes homogenous groups, $p \leq 0.05$, other explanations as described under Figure 1 .

The amount of fat and the share of $\beta$-glucan (BC) in the composition of muffins had an impact on their appearance (external and crumb). Bakery goods with the largest share of BC (MBG4) differed statistically significantly $(p \leq 0.05)$ from other products in terms of the number of cracks on the surface. The addition of this polysaccharide above $2 \%$ (with a fat reduction above $40 \%$ ) caused a significant change in color, and above $3 \%(60 \%$ fat reduction) resulted in poorer evenness of bake.

Panelists stated that only a 3\% share of $\beta$-glucan ( $60 \%$ fat reduction) caused a significant change in the color of the crumb. However, only the porosity of the control sample was considered uniform, and the remaining samples in their assessment were worse in this characteristic.

Texture is a key attribute both in terms of sensory quality and in meeting consumer expectations regarding the type of cake or brand [36]. Tested $\beta$-glucan samples obtained the lowest texture scores (Springiness, Guminess). Along with the decreasing fat content and the increase in the substitutes used, the hardness of muffins was getting higher and their springiness decreased. Similar results were obtained by Laguna et al. [36] who showed that a fat substitute increased the biscuit's hardness. Moreover, replacing more than $15 \%$ fat with inulin causes a deterioration in the quality of their texture [37]. Zoulias et al. [38] noted that a high hardness value is an unpleasant characteristic for cake product.

According to panelists, the tested samples were the least diverse in terms of gumminess (Table 3).

The samples tested were also different in taste and aroma. Typical taste and smell was the most intense in the control sample (MBG0) and its intensity decreased with the increase in $\beta$-glucan and thus the degree of fat substitution. However, in MBG0 and MBG1 the most intense was the oil smell, considered by panelists as undesirable. The foreign flavor and odor was most intense in samples with the largest share of $\beta$-glucan (MBG3 and MBG4).

In summary, the overall quality of the products has decreased with the increase of $\beta$-glucan in their composition. The muffins with the lowest amount of microbial polysaccharide additive (MBG1 and MBG0) did not differ statistically in terms of desirability. In other works, it was also noted that reducing fat content and replacing it with dietary fiber causes a decrease in the sensory quality of confectionery products [21,31]. Seker et al. [39] studied the sensory effect of apricot kernel flour in biscuits to replace up to $40 \mathrm{~g} / 100 \mathrm{~g}$ fat, obtaining acceptability assessments that did not differ significantly from controls. Żbikowska et al. [31] also reported that replacing $25 \%$ of fat with microcrystalline cellulose had the desired effects because the new products were of high sensory quality. Finally, according to Mohebbi et al. [40] sensory evaluation showed that the use of prebiotic $\beta$-glucan $(0.8 \%-1.2 \%)$ has no negative impact on the quality of bread. 
Zoulias et al. [41] noted that the sensory limit for fat replacement in a cookie formulation (with $40 \mathrm{~g}$ of fat per $100 \mathrm{~g}$ flour) was $50 \%$ because of the decrease in overall quality. The use of fiber instead of fat may be beneficial because new products may meet the criteria for claims on fiber content in foods. It has been observed that inulin is a very effective alternative to fat in bakery products. The level of fat replacement in crackers and cakes up to $75 \%$ was able to reduce the calorific value of products without any change in consumer acceptance. It should be added, however, that the addition of inulin changed the texture and physical properties of the listed products [9].

\subsection{Muffin Quality Analysis during Storage}

During the first 7 days of storage, significant changes in the water content of the muffins were found. They particularly concerned samples with $\beta$-glucan. Over the next 7 days of the test, a much smaller decrease in humidity of all products was noted (the smallest by $0.22 \%$ for MGB 0 and the largest by $1.42 \%$ for MBG4). Within 14 days of storage, the largest water loss occurred in products with the largest share of $\beta$-glucan (by 3.63\%). Humidity is one of the key and desirable features shaping the sensory values of the product, because it increases the softness of the crumb.

Fat is also a component responsible for shelf life [8]. It affects the texture quality of cakes, which is one of the indicators of their freshness and desirability during storage. The textural change of the cakes may be affected by many factors such as water transfer, solubility of components, and degradation of other components such as lipids or proteins [42]. The texture of all tested muffins changed during their storage (Figure 4).

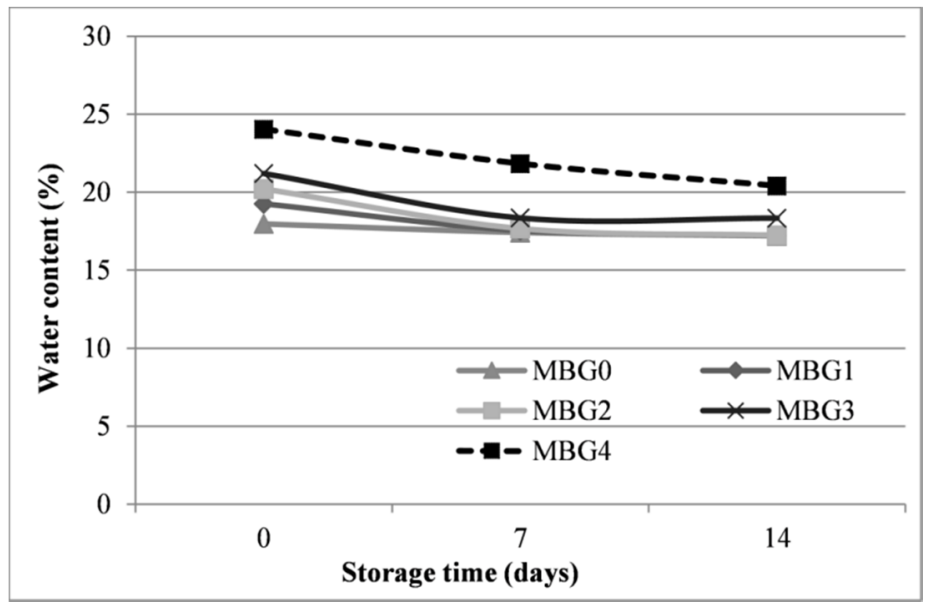

Figure 4. Water content in muffins during 14 days storage. Explanations under Figure 1.

The biggest changes occurred in the hardness of products, regardless of their type. However, the value of this parameter increased the fastest in muffins with the largest $\beta$-glucan (BG) addition and with the highest fat elimination ( $80 \%$ ). It has been shown that the higher the proportion of BG addition, the crumb hardness faster increased over time. No such clear trend was found for the other texture parameters (Figure 4). Similar relationships were reported by Kaling and Mishra [26], who studied the effect of 20,30 , and $40 \%$ fat substitution with oat and barley $\beta$-glucan concentrate on the texture of cakes (hardness, cohesiveness, springiness). Researchers have observed a steady increase in the hardness of products with $\mathrm{BC}$ over time, and the deterioration of texture parameters was the stronger with more polysaccharide added to the batter recipe. In addition, the scientists did not notice significant changes in the cohesiveness and springiness of cakes under the influence of $\beta$-glucans during storage. Changes in the texture of pastry products testify to the progressing process of staling.

The elimination of fat by the addition of this bioactive ingredient accelerates the rate of adverse changes in texture quality (Figure 5), which may be related to the decreasing water content in muffins (Figure 4). 

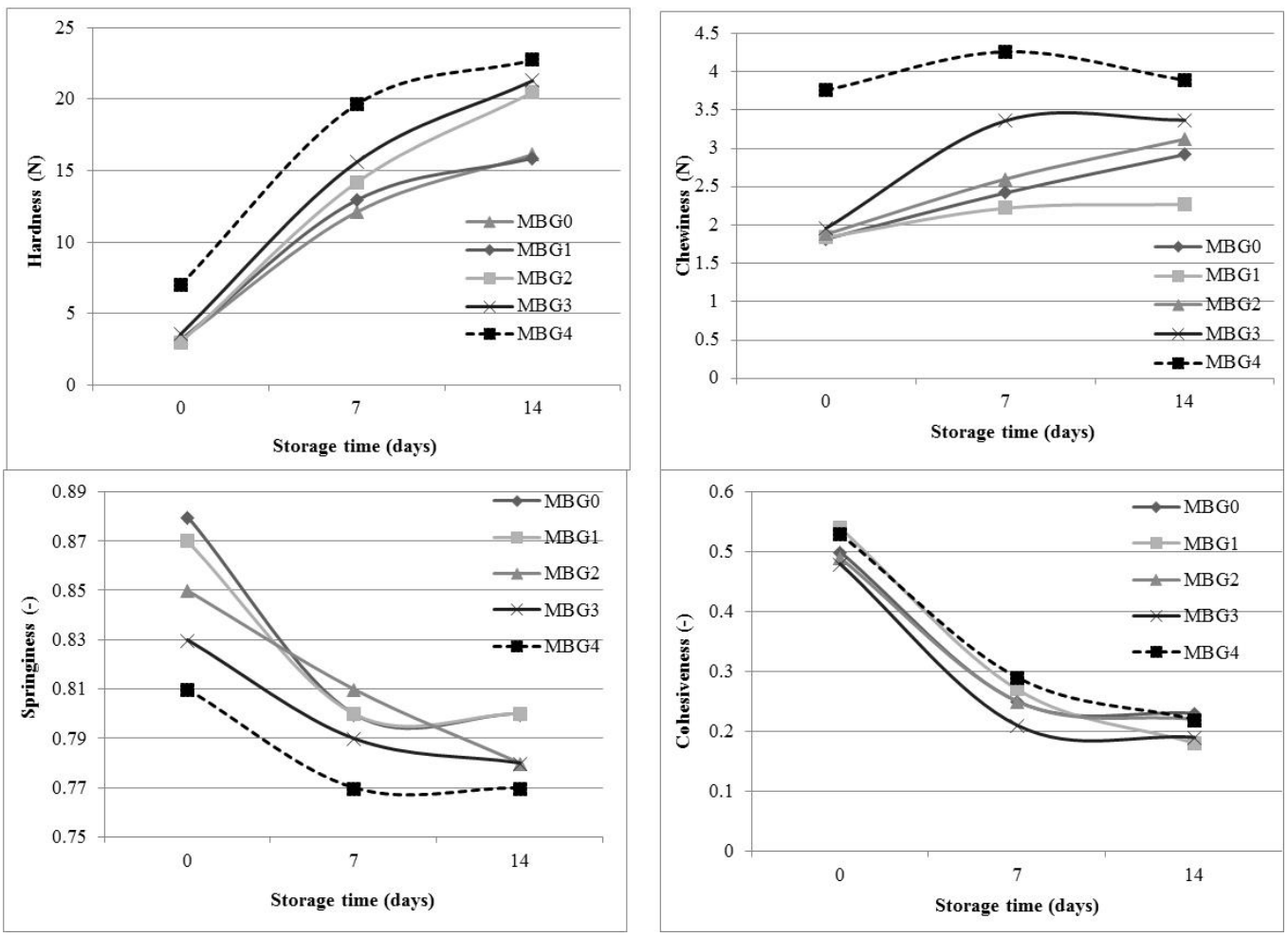

Figure 5. Texture parameters of muffin during 14 days storage. Explanations as described under Figure 1.

\section{Conclusions}

Microorganisms can be an useful source of bioactive food ingredients. $\beta$-glucan (BC) obtained from yeast may be used in the production of muffins with increased nutritional value and reduced fat content. However, the results indicate the possibility of eliminating fat from muffins by replacing it with this polysaccharide obtained from microorganisms, to a limited extent. Substitution of fat above $40 \%$, while enriching muffins with $\beta$-glucan, led to a decrease in the quality of products both after baking and during their storage. The introduction of $3 \%$ and more $\mathrm{BC}$ to the composition, while reducing fat (60\% and more), caused an undesirable increase in the hardness of the batter and deterioration of the quality of the muffin crumb, after baking and during storage. In addition, such products were less desirable in terms of sensory quality, which was mainly due to an increase in hardness and a decrease in springiness of the crumb, as well as an increase in perceptibility/intensity of foreign/untypical flavor and odor.

Author Contributions: Conceptualization, A.Ż.; methodology, A.Ż. and I.S.; validation, A.Ż., I.S., M.K. (Małgorzata Kowalska), and K.M.-L.; formal analysis, A.Ż., I.S., M.K. (Milena Kupiec), and K.O.; data curation, A.Ż., M.K. (Małgorzata Kowalska), K.M.-L., and J.R.; writing—original draft preparation, A.Ż.; writing—review and editing, I.S., M.K. (Milena Kupiec), M.K. (Małgorzata Kowalska), J.R., K.M.-L.; visualization, M.K. (Małgorzata Kowalska) and J.R. All authors have read and agreed to the published version of the manuscript.

Funding: This research was funded by Warsaw University of Life Sciences.

Conflicts of Interest: The authors declare no conflict of interest.

\section{References}

1. FAO. The State of Food Insecurity in the World 2008. High food Prices and Food Security-Threats and Opportunities; FAO: Rome, Italy, 2008.

2. Tanhatan-Nasseri, A.; Rasoul-Amini, S.; Morowvat, M.H.; Ghasemi, Y. Single Cell Protein: Production and Process. Am. J. Food Technol. 2011, 6, 103-116. 
3. Jamas, S. Controlled Biosynthesis of Yeast Glucans; MIT: Cambridge, MA, USA, 1987; pp. 1-171.

4. Du, B.; Bian, Z.; Xu, B. Skin Health Promotion Effects of Natural Beta-Glucan Derived from Cereals and Microorganisms: A Review. Phytotherm. Res. 2014, 28, 159-166. [CrossRef] [PubMed]

5. Vannucci, L.; Krizan, J.; Sima, P.; Stakheev, D.; Caja, F.; Rajsiglova, L.; Horak, V.; Saieh, M. Immunostimulatory properties and antitumor activities of glucans (Review). Int. J. Oncol. 2013, 43, 357-364. [CrossRef]

6. Vetvicka, V.; Vetvickova, J. Physiological effects of different types of $\beta$-glucan. Biomed. Pap. Med. Fac. Palacky Univ. Olomouc 2007, 151, 225-231. [CrossRef] [PubMed]

7. Grigor, J.M.; Brennan, C.S.; Hutchings, S.C.; Rowlands, D.S. The sensory acceptance of fibre-enriched cereal foods: A meta-analysis. Int. J. Food Sci. Technol. 2016, 51, 3-13. [CrossRef]

8. Barak, S.; Mudgil, D.; Khatkar, B.S. Effect of flour particle size and damaged starch on the quality of cookies. J. Food Sci. Technol. 2014, 51, 1342-1348. [CrossRef]

9. Colla, K.; Costanzo, A.; Gamlath, S. Fat replacers in baked food products. Foods 2018, 7, 192. [CrossRef]

10. Rodriguez-Garcia, J.; Laguna, L.; Puig, A.; Salvador, A.; Hernando, I. Effect of fat replacement by inulin on textural and structural properties of short dough biscuits. J. Food Sci. 2012, 77, 189-197. [CrossRef]

11. Zbikowska, A.; Kozlowska, M.; Poltorak, A.; Kowalska, M.; Rutkowska, J.; Kupiec, M. Effect of addition of plant extracts on the durability and sensory properties of oat flake cookies. J. Therm. Anal. Calorim. 2018, 134, 1101-1111. [CrossRef]

12. Willett, W.; Rockstrom, J.; Loken, B.; Springmann, M.; Lang, T.; Vermeulen, S.; Garnett, T.; Tilman, D.; DeClerck, F.; Wood, A.; et al. Food in the Anthropocene: The EAT-Lancet Commission on healthy diets from sustainable food systems. Lancet 2019, 393, 447-492. [CrossRef]

13. Eilander, A.; Harika, R.K.; Zock, P.L. Intake and sources of dietary fatty acids in Europe: Are current population intakes of fats aligned with dietary recommendations? Eur. J. Lipid Sci. Technol. 2015, 117, 1370-1377. [CrossRef]

14. Onacik-Gür, S.; Zbikowska, A. Effect of high-oleic rapeseed oil oleogels on the quality of short-dough biscuits and fat migration. J. Food Sci. Technol. 2019, 1-10. [CrossRef]

15. Zbikowska, A.; Onacik-Gür, S.; Kowalska, M.; Rutkowska, J. Quality and safety of pastry products in Poland in respect of fatty acids composition, especially trans fatty acid content in fats. J. Food Protect. 2019, 82, 1028-1033.

16. Regulation (Ec) No 1924/2006 of the European Parliament and of the Council of 20 December 2006 on Nutrition and Health Claims Made on Foods. Available online: https://eur-lex.europa.eu/legal-content/EN/ TXT/PDF/?uri=CELEX:32006R1924 (accessed on 26 February 2020).

17. Yılmaz, E.; Öğütcü, M. Properties and stability of hazelnut oil organogels with beeswax and monoglyceride. J. Am. Oil Chem. Soc. 2014, 91, 1007-1017. [CrossRef]

18. Onacik-Gür, S.; Zbikowska, A.; Kapler, E.; Kowalska, H. Effect of barley b-glucan addition as a fat replacer on muffin quality. Acta Sci. Pol. Technol. Aliment. 2016, 15, 247-256. [CrossRef]

19. Barylko-Pikielna, N.; Matuszewska, I. Sensoryczne Badania Zywnosci. Podstawy-Metody-Zastosowanie; PTTZ Publishing: Krakow, Poland, 2009; pp. 227-242.

20. Manohar, R.S.; Rao, P.H. Effects of emulsifiers, fat level and type on the rheological characteristics of biscuit dough and quality of biscuits. J. Sci. Food Agric. 1999, 79, 1223. [CrossRef]

21. Zbikowska, A.; Kowalska, M. The use of apple fiber as a fat substitute in the manufacture of bakery products. J. Food Process. Preserv. 2017, 41, e13241. [CrossRef]

22. Ghodke, S.K. Effect of guar gum on dough stickiness and staling in Chapatti: An Indian unleavened flat bread. Int. J. Food Eng. 2009, 5, 1-19. [CrossRef]

23. Serin, S.; Sayar, S. The effect of the replacement of fat with carbohydrate-based fat replacers on the dough properties and quality of the baked pogaca: A traditional high-fat bakery product. Food Sci. Technol. 2017, 37, 25-32. [CrossRef]

24. O'Brien, C.M.; Mueller, A.; Scannell, A.G.M.; Arendt, E.K. Evaluation of the effects of fat replacers on the quality of wheat bread. J. Food Eng. 2003, 56, 265-267. [CrossRef]

25. Rutkowska, J.; Zbikowska, A. Effects of fatty acids composition of liquid margarines on sensory quality of cakes. Acta Aliment. 2010, 39, 125-137. [CrossRef]

26. Kalinga, D.; Mishra, V.K. Rheological and physical properties of low fat cakes produced by addition of cereal $\beta$-glucan concentrates. J. Food Process. Preserv. 2009, 33, 384-400. [CrossRef] 
27. Indrani, D.; Rao, G.V. Functions of ingredients in the baking of sweet goods. In Food Engineering Aspects of Baking Sweet Goods; Sumnu, S.G., Sahin, S., Eds.; CRC Press: Boca Raton, FL, USA, 2008; pp. 31-47.

28. Zahn, S.; Pepke, F.; Rohm, H. Effect of inulin as a fat replacer on texture and sensory properties of muffins. Int. J. Food Sci. Technol. 2010, 45, 2531-2537. [CrossRef]

29. Dadkah, A.; Hashemiravan, M.; Seyedain-Ardebili, M. Effect of shortening replacement with nutrim oat bran on chemical and physical properties of shortened cakes. Ann. Biol. Res. 2012, 3, 2682-2687.

30. Devi, A.; Khatkar, B.S. Physicochemical, rheological and functional properties of fats and oils in relation to cookie quality: A review. J. Food Sci. Technol. 2016, 53, 3633-3641. [CrossRef]

31. Zbikowska, A.; Kowalska, M.; Pieniowska, J. Assessment of shortcrust biscuits with reduced fat content of microcrystalline cellulose and psyllium as fat replacements. J. Food Process. Preserv. 2018, 42, e13675. [CrossRef]

32. Martinez-Cervera, S.; Hera, E.; Sanz, T.; Gomez, M.; Salvador, A. Effect of nutriose on rheological, textural and characteristics of Spanish muffins. Food Bioprocess Technol. 2013, 6, 1990-1999. [CrossRef]

33. Rodríguez-García, J.; Sahi, S.S.; Hernando, I. Functionality of lipase and emulsifiers in low-fat cakes with inulin. LWT-Food Sci. Technol. 2014, 58, 173-182. [CrossRef]

34. Sanz, T.; Salvador, A.; Baixauli, R.; Fiszman, S.M. Evaluation of four types of resistant starch in muffins. II. Effects in texture, colour and consumer response. Eur. Food Res Technol. 2009, 229, 197-204. [CrossRef]

35. Martínez-Cervera, S.; Sanz, T.; Salvador, A.; Fiszman, S.M. Rheological, textural and sensorial properties of low-sucrose muffins reformulated with sucralose/polydextrose. LWT-Food Sci. Technol. 2012, 25, $213-220$. [CrossRef]

36. Laguna, L.; Varela, P.; Salvador, A.; Sanz, T.; Fiszman, S.M. Balancing Texture and Other Sensory Features in Reduced Fat Short-Dough Biscuits. J. Texture Stud. 2012, 43, 235-245. [CrossRef]

37. Laguna, L.; Primo-Martín, C.; Varela, P.; Salvador, A.; Sanz, T. HPMC and inulin as fat replacers in biscuits: Sensory and instrumental evaluation. LWT-Food Sci. Technol. 2013, 30, 494-501. [CrossRef]

38. Zoulias, E.I.; Oreopoulou, V.; Tzia, C. Textural properties of low-fat cookies containing carbohydrate- or protein-based fat replacers. J. Food Eng. 2002, 55, 337-342. [CrossRef]

39. Seker, I.T.; Ozboy-Ozbas, O.; Ozturk, S.; Koksel, H. Utilization of Apricot Kernel Flour as fat replacer in cookies. J. Food Process. Preserv. 2010, 34, 15-26. [CrossRef]

40. Mohebbi, Z.; Homayouni, A.; Azizi, M.H.; Hosseini, S.J. Effects of beta-glucan and resistant starch on wheat dough and prebiotic bread properties. J. Food Sci. Technol. 2018, 55, 101-110. [CrossRef] [PubMed]

41. Zoulias, E.I.; Oreopoulou, V.; Kounalaki, E. Effect of fat and sugar replacement on cookie properties. J. Sci. Food Agric. 2002, 82, 1637-1644. [CrossRef]

42. Gomez, M.; Ruiz-Paris, E.; Oliete, B.; Pando, V. Modelling of texture evolution of cakes during storage. J. Texture Stud. 2010, 41, 17-33. [CrossRef]

(C) 2020 by the authors. Licensee MDPI, Basel, Switzerland. This article is an open access article distributed under the terms and conditions of the Creative Commons Attribution (CC BY) license (http://creativecommons.org/licenses/by/4.0/). 